\title{
Building on the Border: Architecture as a Meeting Place
}

\author{
By Francesco Del Sole*
}

To establish a border signifies defining a fixed point from which to start and to which to refer in order to circumscribe controlled and measured environments. It is not important whether it is a border between states and regions or private and public spaces, because the main effect of the border is to sanction a diversity. This proposal will analyse three case-studies that, starting from antiquity to the contemporary age, have proposed over time different ways of conceiving the border, making architecture the convergence point. The first is the Temple of Diana at Ephesus, a monument created by Greek artists located in Persian territory. It stood on the peninsula of Anatolia, the border land par excellence in the Hellenistic world, a place where the dominant Western cultures of Greece and Persia clashed. The second is Castel Velturno, a border utopia belonging to Prince-Bishop Cristoforo Madruzzo, who deposited his dreams of unification between the North and the South of Christianity which were torn apart by the theological demands addressed during the Council of Trento. Finally, this proposal will examine the contemporary project entitled the Bi-National Community Skyscraper, which proposes a reinterpretation of the walls erected on the border between the USA and Mexico by building a skyscraper on it in which the two communities can meet and merge together.

\section{Introduction}

A border is identified as that sign which, by delimiting a territory, divides two places. The act which underlies the meaning of this term is of a man, who has different cultural attitudes and has defined different characteristics and forms of the border over time, taking possession of the territory. ${ }^{1}$

In addition to identifying the border only as a material sign, it is necessary to widen the scope of its meaning to areas that are not purely architectural in order to understand the complexity of this concept. This also takes on a more abstract sense of term and limit: "borders die and rise again, they move, they are erased and reappear unexpectedly. They mark the experience, the language, the space of living, the body with its health and illnesses, the psyche with its divisions and rearrangements, politics with its often absurd cartography, the ego with the plurality of its fragments and their laborious recompositions, society with its

\footnotetext{
*Assistant Professor, Department of Cultural Heritage, University of Salento, Italy.

1. On the subject of the border, within the border studies, see above all P. Zanini, Significati del Confine. I Limiti Naturali, Storici, Mentali (Milano: Mondadori, 1997); M. Augè, Tra i Confini. Città, Luoghi, Integrazioni (Milan: Mondadori, 2007); B. Albrecht and L. Benevolo, I Confini del Paesaggio Umano (Rome-Bari: Laterza, 1994); A. C. Varzi, "Teoria e Pratica dei Confini," Sistemi Intelligenti 17, no. 3 (2005): 399-418; G. Paba (Ed.) La Città e il Limite. I Confini della Città (Florence: La Casa Usher, 1990).
} 
divisions, the economy with its invasions and retreats, thought with its maps of order." 2

It is necessary to highlight the distinction between border and frontier. The border indicates a common boundary, a way of establishing one's right in a disputed area; the frontier, on the other hand, is the ultimate limit beyond which to venture, it is directed against something or someone. Beyond it you become a foreigner and a different person.

The natural border has always been considered the best line to define the limits of a state and to guarantee its defence, since it follows the homogeneous geographical characteristics of a territory. In history, however, borders have often been drawn using straight lines on maps. In this regard, the boundary is a simple abstract sign that testifies the taking of possession of a territory and sanctions its ownership, modifying and superimposing itself on the physical state of the place. The first boundaries of man on Earth have been largely erased, because they were unstable and unfixed borders that came about from a unified vision of the unlimited natural landscape with which man maintained a certain confidence. ${ }^{3}$ With the formation of cities, the conceptual meaning of boundaries, together with the ways and forms of delimitation, became more complex: the main need was then to establish discontinuity between the natural exterior and the built and regulated urban interior. ${ }^{4}$ In the city, the rules of city living are established and the realization of the urban space, artificial and complex, defines the modalities of the relationships between the people who live there: "The city, within its walls, is culture, the seat of values. Outside it [...] there is the non-civility, the countryside, and the anti-city, the desert-forest." The urban border, on the one hand, configures the city as an autonomous element with a strong formal identity to which the citizen feels they belong; on the other, because of the fear of external invasions, it takes on a defensive and military character. Over time, the military character of the border has become a sign of the city's control and domination over the countryside: "military borders [...] become networks of fortresses, rationally spaced out and surrounded by empty spaces. Some of them take the form of cities entirely subordinate to the warlike function, i.e., purposely located and conformed." 6

\section{The New Invisible Boundaries: The Social Boundary}

"Today's great metropolis is crossed by a myriad of boundary lines, barely recognisable, due to uncertain and changing signs, only by the exercised eye of the new metropolitan traveller. These invisible borders trace a strange and sometimes

2. C. Magris, “Come i Pesci il Mare," Frontiere - Nuovi Argomenti 38 (1991), 12.

3. The Avebury Circle, in Wiltshire, is an example of a boundary marked by man in the Neolithic period, which does not become a world in its own right as opposed to the landscape, but tries to integrate with it. The boundary is a large circle of 450 meters in diameter, made up of stones flanked by a moat, whose excavated material, brought back to the outside, forms the embankment. The boundary marks the passage to a sacred area with the sky as its ceiling.

4. See J. Rykwert and G. Scattone, L'idea di Città. Antropologia della Forma Urbana nel Mondo Antico (Turin: Einaudi, 1981).

5. Albrecht and Benevolo, I Confini del Paesaggio Umano, 1994, 9.

6. F. Rella, Metamorfosi: Immagini del Pensiero (Milan: Feltrinelli, 1984), 71. 
dangerous geography, cutting through streets, neighbourhoods, crossroads in an apparently senseless way. They also divide the inhabitants of the day from the inhabitants of the night. They delimit territories of hunting and robbery and places of respite and peace, where hunters and prey eventually rest restlessly, waiting for a new escape and a new pursuit." 7 This margin of the border between two worlds also exists because of the invisible lines that create social divisions within the city. ${ }^{8}$ The border, in this case, is a symbol of inclusion or exclusion from a community. Social boundaries have always been raised by man; by gathering together in groups accumulated by customs and habits, he has created communal lines through behaviours and principles, which lead the community back to a welldefined and opposing identity. "We think of castes, ethnicities, [...] nations, classes, parties, factions, quarters." "Usually, these are social boundaries that do not necessarily need a territorial projection, even though there can often be a correspondence. In this case, the border, although not marked by a physical object, is where there is a gap or an incoherence between the two different parts that divides people: "I don't understand you, you are really strange and belonging to another world. I can even try to drag you into mine by force, but that doesn't change the fact that you are different and elsewhere." definition and perception of borders have conveyed a multidisciplinary scientific interest from which border studies was born. ${ }^{11}$ The historical processes of building material boundaries are intertwined with the identification of identities and affiliations of social communities and together, they constitute an important reference for the search of the contemporary border. Establishing a border, therefore, means founding a space by defining a fixed point from which to start and to which to refer. Marked in this way, the borders circumscribe controlled, measured and recognisable environments. The boundary line can be physical or imaginary, defined by architectural elements or by invisible lines drawn on maps. It has an interscalar character; it is not important that it is a border between states, regions, or private and public spaces, because the sensation you feel when you cross a border is always that of a change. This is due to the difference in the appearance of the two places due to different rules, uses and customs that characterise each. The complete idea of a border, given by the interpenetration between physical and social margins, fulfils a fundamental task: to indicate the place of a difference, real or presumed. As La Cecla says, "[the border is] the

7. Ibid, 69.

8. On the social and anthropological subject of the border it is useful to consult the studies of Franco la Cecla. In particular see F. La Cecla, Il Malinteso: Antropologia dell'Incontro (Rome-Bari: Laterza, 2003); La Cecla, Mente Locale, per un'Antropologia dell'Abitare (Milan: Eleuthera, 1993).

9. U. Fabietti, "La Costruzione dei Confini in Antropologia. Pratiche e Rappresentazioni," in Confini: Costruzioni, Attraversamenti, Rappresentazioni (Soveria Mannelli: Rubbettino, 2005), 177.

10. La Cecla, Il Malinteso: Antropologia dell'Incontro, 2003, 167.

11. S. Salvatici, (Eds.) Confini: Costruzioni, Attraversamenti, Rappresentazioni. (Soveria Mannelli: Rubbettino, 2005), 7. The book, which collects the contributions presented at the conference entitled "Confini" (Bolzano, 2004), is useful for an in-depth examination of the topic of borders in an interdisciplinary context. 
space in which cultures explain and confront each other, discovering different ones. The misunderstanding is the border that takes shape." 12

Through the analysis of three case-studies, starting from antiquity to the contemporary age, an attempt will be made to highlight the power that architecture has had throughout history to show all the ways in which the border can be experienced and have proposed different ways of conceiving the border, making architecture the meeting place. This is achieved through an idea implemented several times in the past that could allow us to understand, even today, that "there is a mutual advantage in recognizing the values of both sides." 13

\section{The Temple of Artemis at Ephesus}

The Temple of Diana at Ephesus is a monument created by Greek artists in Persian territory. It was located on the peninsula of Anatolia, the border land par excellence of the Hellenistic world, a place where the dominant western cultures of Greece and Persia clashed. The main reason why it was included in the famous canon of the seven wonders of the ancient world is its intercultural character.

The canon of the Wonders of the World was drawn up in the Hellenistic age, when Alexander the Great's empire was slowly crumbling. ${ }^{14}$ At the time of the death of the Macedonian sovereign in 323 B.C., the peoples of the Mediterranean and the Near East were faced with infighting between all the Dyads. This was the main pivot of contemporary history which gave rise to a single certainty that historians uphold: the age of prosperity and greatness of the Hellenic world had come to a drastic end. In other words, we had passed from a time when Greece and its models had constituted a common denominator for the whole world to a period of slow decay until the fall of the greater world sense of greed. It is precisely this important historical passage that pushed the intellectuals of the $3^{\text {rd }}$ century B.C. to draw up a testament to indicate where man was able to go in the "ancient" epochs by highlighting the results he had achieved. Thus, the canon of the Wonders of the

12. La Cecla, Il Malinteso: Antropologia dell'Incontro, 2003, 162.

13. A. Angelillo and C. Menato, Città di Confine. Conversazioni sul Futuro di Gorizia e Nova Gorica (Portogruaro: Ediciclo, 1994), 16. To fully understand the importance of border architecture, it is useful to consult the extensive studies on the relationship between architecture, local identities and globalisation. In particular see A. Giddens, Modernity and Self-Identity (London: Polity Press, 1991); F. Remotti, Contro l'Identità (Bari: Laterza, 1996); L. Gallino, Globalizzazione e Disuguaglianze (Bari: Laterza, 2001); P. Herle and E. Wegerhoff, Architecture and Identity (Berlin: Lit Verlag, 2009); A. Magnaghi, Il Progetto Locale. Verso la Coscienza di Luogo (Turin: Bollati Berlinghieri, 2010); V. B. Canizaro, Architectural Regionalism: Collected Writings on Place, Identity, Modernity and Tradition (New York: Princeton Architectural Press, 2012).

14. On the theme of the Wonders of the World see M. Fagiolo, "Le Meraviglie e il Meraviglioso," Psicon. Rivista Internazionale di Architettura, 7, no. III (1976): 3-9; M. L. Madonna, "Septem Mundi Miracula come Templi della Virtù," Psicon. Rivista Internazionale di Architettura 7, no. III (1976): 25-31; P. A. Clayton and M. J. Price, Seven Wonders of the World (Turin: Einaudi, 1989); F. Del Sole, Viaggio nella Meraviglia: Descrivere, Immaginare, RiCostruire (Galatina: Congedo, 2019); Del Sole, The Gift of the Spoken Word: The Word-Image Relationship in the Memory Process, in New Approaches in Contemporary Architecture and Urbanism (ed.) H. A. Nia. Cinius Yayınlar1: Alanya, 2020, 106-114. 
World was born. The common thread which underlies the choice of the seven Mirabilia is the character of universality. Seeing the disastrous results of the fragmentary nature that Alexander had bequeathed, it was decided that those architectural works that were the symbol of eras in which the world proposed universal models of integration between peoples were to be remembered and handed down as a model of prosperity for future generations. It is emblematic that all the ancient sources on the subject do not speak of the Wonders of one civilization or another; they speak of the Wonders of the World, making this historical operation one of the first examples of interculturality in which the protagonist is man who is featured alongside his history. If the first two wonders represent the two phases of man's most ancient history (Egypt and Babylon), the other four represent the most recent stages of Mediterranean history. Strongly symbolic, among the others, is the choice to include, among the seven Spectacula, the Temple of Artemis at Ephesus. Located on the peninsula of Anatolia on the border between Greece and Persia, together with the Mausoleum of Halicarnassus, this building represents to historians the phase of coexistence and opposition between two great populations that dominated the Mediterranean: the Persians and the Greeks. ${ }^{15}$ What is important to highlight in these two structures is the confluence of the Persian-Eastern scheme with the Greek one (and vice versa). In the canon of the Wonders, the second age of the world, after the EgyptianBabylonian one, is the coexistence of the two great cultures of Greece and Persia. The construction of the Temple dedicated to Artemis began in the 6th century B.C., at a time when the Greek cities of Asia Minor had fallen under the dominion of Creso, the King of Lydia. Its construction was very long, requiring the contribution of several generations and continuing, therefore, even after Lydia was annexed by Cyrus to the Persian Empire. ${ }^{16}$ All of the Greek spirit of the time was channelled into this majestic work, which was enriched by characters and elements from the culture of the Near East ${ }^{17}$ (Figure 1).

15. On the Temple of Diana at Ephesus, in addition to the ancient sources, reference is made to: E. Falkener, Ephesus, and the Temple of Diana (London, Polity Press, 1862); P. A. Clayton and M. J. Price, Seven Wonders of the World (Turin: Einaudi, 1989), 75-94; A. Bammer, "A Peripteros of the Geometric Period in the Artemision of Ephesus," Anatolian Studies 40 (1990): 137-160; L. R. LiDonnici, "The Images of Artemis Ephesia and Greco-Roman Worship: A Reconsideration," Harvard Theological Review 85, no. 4 (1992): 389-415; G. Rocco, "Guida alla Lettura degli Ordini Architettonici Antichi. II. Lo Ionico," in Guide di Ricerca Storica e Restauro 4, 75-82. Naples: Liguori Editore, 2003; C. Bozzoni, V. Franchetti Pardo, G. Ortolani and A. Viscogliosi, L'architettura del Mondo Antico (Bari: Laterza, 2006).

16. The most important and oldest building (called " $\mathrm{D}$ " by the archaeologists) was built by order of Creso around the middle of the $7^{\text {th }}$ century; we have as evidence of this some inscriptions in Greek and Lidi characters that were on the columns of the temple. It was destroyed on $21^{\text {st }}$ July 356 B.C. by a certain Erostatus, who set it on fire thinking in this way to make its name immortal.

17. "It is enough to look at the reconstruction of the temple to understand its oriental influences. It is believed that in the $7^{\text {th }}$ century the sanctuary consisted of a structure similar to an altar and two other monuments: the Hekatompedon (so called because it measured 100 feet) and the ramp altar. All this was covered with the construction of the temple "D" and the altar courtyard. The temple " $D$ " had eight columns on the facade and nine on the back, it was not supposed to be a hypetro, although some scholars claim that it was open to the rain, because in the area of the cell was found a pipe that was used to eliminate water. Later it was thought that the roof was truncated and limited to the colonnade, i.e. the central part was uncovered. Access to the high terrace of the 

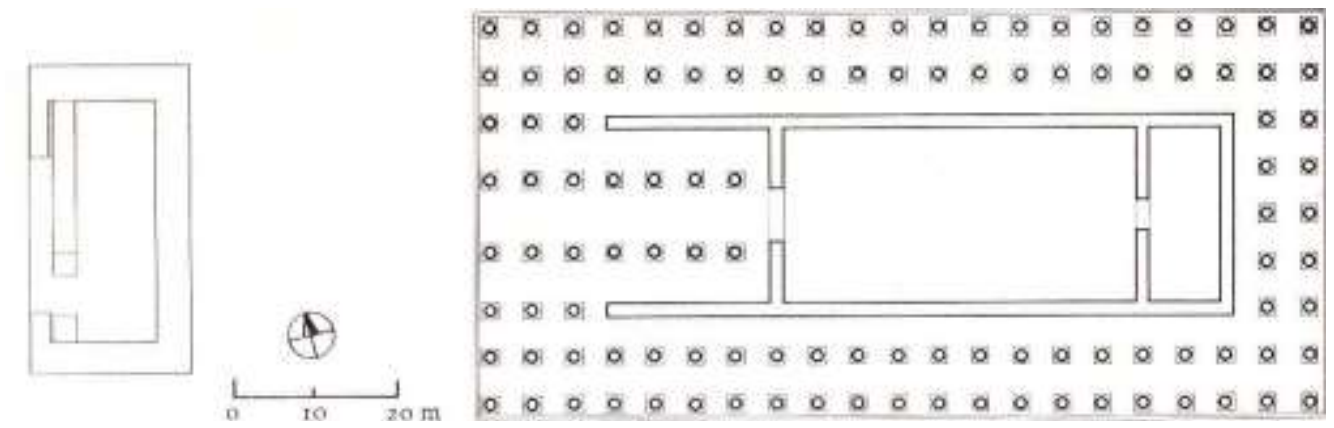

Figure 1. Plan of the Late Classical Temple of Artemis in Ephesus and the Courtyard with the Altar according to the Description of Pliny the Elder Source: Clayton and Price 1989, 77.

Following the sources, it also seems that many of the great names of classical Greek art $\left(5^{\text {th }}\right.$ and $4^{\text {th }}$ centuries B.C.) alternated in this site: Phidias, Polyclitus, Cresila, Fradmon and, finally, Prassitele. ${ }^{18}$ This $5^{\text {th }}$ century B.C. sculpture competition was unique because the artists "were invited to exhibit [the sculptures] in public, and the four most beautiful were then chosen to decorate Temple D." In one of his passages, Gibbon (1780) highlights the popular idea that led Artemision to be considered a Wonder was the fact that it was a "meeting point"

sanctuary was by means of marble steps built around the building like a gigantic frame. The high base was 7.85 meters wide and 131 meters long. Pliny tells us that the columns were 20 meters high, slender and elegantly grooved (Ionic style), beautiful capitals supported the beams so big that a legend was born about an intervention of the same goddess to help the architect to erect them; in fact, discouraged by the difficulty of the undertaking, he was contemplating suicide. The frieze had no figures but only a large indentation on the highest selvedge supporting the tympanum. The tympanum had three openings or windows: the central one had doors and two statues of Amazons stood next to it. Pliny speaks of 127 columns in the complex. The cell was located exactly in the centre of the building. The strange statue with many breasts of Artemis Ephesia represents a mother goddess. The statue is rigid, the lower part resembles the sarcophagus of an Egyptian mummy. If Pliny makes it perfectly clear that the structure is one of the greatest examples of Greek architecture, there are many oriental elements: the sacrificial altar, placed in the cell at a certain distance from the temple façade, was in an asymmetrical position. This arrangement is linked to the Near East, where the temples sometimes had a side entrance and not on the forehead; there were many decorative elements: deer, lions, griffins, sphinxes, sirens and bees; appearance of Artemis' dramatis personae: three openings were made in the tympanum and the goddess often appeared (in the central opening), as if she were appearing, so that her worshippers could see her". Clayton and Price, Seven Wonders of the World, 1989, 75 ss.

18. "Among the most illustrious bronze artists there was a competition despite the differences in age; since they had sculpted Amazons, when they dedicated them in the Temple of Diana at Ephesus, it was decided to choose the most beautiful one according to the opinion of the artists themselves [...] The victory went to Polyclitus, the second to Phidias, the third to Cresila, the fourth to Cidon, the fifth to Fradmon" [Pliny the Elder, Naturalis Historia (Pisa: Giardini, 1985), XVI, 213-215]; "When the Temple was finished, most of the statues were provided with other honours for the artists, but the altar was almost entirely supplied with works by Prassitele. [...] They kept eunuchs as priests, and always looked for them from outside, people who were worthy of such distinction" [Strabo, Geography (Milan: Rizzoli, 1993), XIV]. On this theme see M. Barbanera, "Favole Antiche e Mitologie Moderne. Le Competizioni Artistiche nella Storia dell'arte Greca," Atene e Roma. Rassegna dell'Associazione Italiana di Cultura Classica VIII, no. 1-2 (2014): 7-31. The reference to the Ephesian temple is on page 20.

19. Clayton and Price, Seven Wonders of the World, 1989, 81. 
between different and hostile civilizations that cooperated in the name of the goddess. ${ }^{20}$ Thus, Artemision generates that "wonder" which contributes to exalt its sacred value. The structure is a complex and unified system of cultural crossroads. It is bizarre to note that, according to Pliny the Elder, the magnificence of Greek architecture is fully expressed in this border work on Persian territory ${ }^{21}$ (Figure 2). He further states that it was in Ephesus that the fundamental characteristics of Greek architecture exhibited by Vitruvius (the use of the capital and the careful system of proportions between the various architectural elements) first appeared, synthesising the greatness of Artemision with the words Graecae magnificae, the first example in the Hellenic world of a structure that seems to be a "forest of columns".

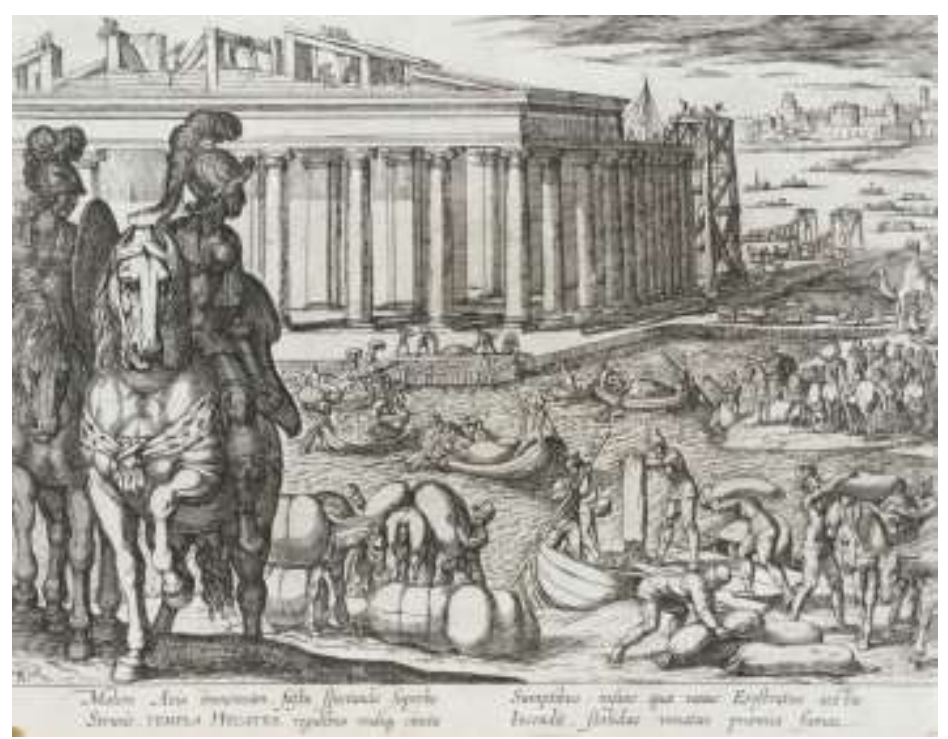

Figure 2. A. Tempesta, The Temple of Artemis at Ephesus (from Septem Orbis Admiranda), 1608

Source: The British Museum - Images Collection - London.

\section{Cristoforo Madruzzo and Castel Velturno}

At the beginning of the $16^{\text {th }}$ century, the European continent raised new and powerful borders. The Protestant reform had a very strong impact on the geography of Europe, becoming the main factor of a cultural identity to be embraced or rejected. Castel Velturno is the materialization of the border as a

20. "Greek arts and Asian wealth had cooperated in the construction of this sacred and splendid structure. [...] the empires that followed, those of Persia, Macedonia and Rome, venerated its holiness and enriched its splendour". From a passage by E. Gibbon of 1780 cit. in Clayton and Price, Seven Wonders of the World, 1989, 75.

21. "A realization of Greek grandeur worthy of true wonder is the temple of Diana which still exists in Ephesus. Its construction took 120 years and the contribution of the whole of Asia. [...] It was in the first temple of Diana at Ephesus that for the first time bulls were placed under the columns and capitals were added, and it was decided that the base diameter of the columns should be one eighth of their height" (Pliny the Elder, Naturalis Historia, 1985, XVI, 213-215). 
space of pacification. It is a utopia built on the borders of the Christian world (Trento) belonging to Prince-Bishop Cristoforo Madruzzo, who deposited in this palace his dreams of pacification between the North and the South of Christianity, torn by the theological needs faced during the Council of Trent. The Protestant Reformation brought not only a profound reflection on Catholic doctrine but a real upheaval of the territorial balances that had been established until then. The Church of Rome seemed to lose its role as the dominant cultural centre, in favour of a Protestant North which was becoming increasingly popular. Therefore, the choosing of the city of Trento as the seat to welcome the Council is emblematic. ${ }^{22}$ Trento was chosen, also thanks to the interest of Charles V, as a border city placed within the limits of the Empire but, at the same time, linked to the politics of the Holy See. It was, thus, capable of expressing the will of the Church of Rome in the first years of the Council to propose a dialogue regarding the ideological demands of German principles.

\section{Cristoforo Madruzzo, Mediator between the Roman Church and the German Princes}

At the time, Trento was ruled by a prince-bishop, Cristoforo Madruzzo, who combined his religious role with his temporal power over the territory. ${ }^{23}$ It was a result of the network of knowledge and relationships of such a personality that the territory of Trento became, in the years of the Council, a real crossroads. His politics perfectly represented the delicate situation of a border land as a "border" which is not only geographical but also ideological and cultural. For this reason, he often insisted that his small frontier territory be assigned a role as a mediator between the defence of Roman orthodoxy and the demands for religious freedom that penetrated the conscience of German princes. The prelate personally lived through all the contrasting events of the Council and, in many ways, tried to influence its outcome. It cannot be denied that, in the course of the Council events, Christopher encountered firm opposition from many prelates. Certainly, one of the factors that annoyed the most conservative souls was the bilingual culture of the bishop. It is obvious that Madruzzo's personality, formed on the border between Italy and the Empire, was influenced by the two cultures in which he grew up: a German one, on his mother's side, and an Italian one, given his cultural formation, which was typically humanistic. It was precisely the nature of his origins that was the main source of his opponents' slander, who even went so far as to accuse him of having supported the Germans from the beginning until he became their leader. Two of Madruzzo's convictions in particular that caused a stir among the ecclesiastics were: his interventions on the themes of justification by faith alone

22. See in particular S. Cavallotto, "Luterani e Cattolici, Storia di un Dialogo Mancato e Ritrovato," Syzetesis V/2 (2018): 227-250; A. Prosperi, L'Eresia del Libro Grande. Storia di Giorgio Siculo e Della sua Setta (Milan: Feltrinelli, 2000).

23. On Cristoforo Madruzzo see C. De Giuliani, "Cristoforo Madruzzo. Giovinezza e Studi, sua Elezione a Principe-Vescovo di Trento e Cardinal," Archivio Trentino 20 (1905): 52-88; L. Dal Prà (Ed.) I Madruzzo e l'Europa 1539-1658. I Principi Vescovi di Trento tra Papato e Impero (Milan: Charta Editore, 1993). 
and the need for the Bible to be translated into the vulgar language. ${ }^{24}$ Madruzzo's support for the ambitions of Charles $\mathrm{V}$ was also met with sympathy for the theories of Reginald Pole, an English cleric who had embraced the doctrine of justification by faith alone, one of the bulwarks of the Lutheran theses and the focal point of the Council's entire doctrinal discussion. ${ }^{25}$ There was also a great deal of fuss over the explicit consent given by Madruzzo to the translation of the Bible into the various national languages, so that the sacred text could be read by everyone, and not only by the ecclesiastical scholars who knew Latin. The relationship between the Protestant Reformation and the national languages would then prove to be one of the key proponents of the spread of the new Lutheran doctrine in Europe, which in turn led to a rediscovery of national identities. The opposition to Madruzzo was, therefore, not uncalled for, since it was understood that resolving the religious-linguistic question would be the starting point of social self-awareness which was very dangerous for the Vatican at a political level. Adriano Prosperi remembers what he proposed, for the positions to be taken among the Council's circles, to begin to observe that strange space that lies between the two parties puts different spaces in contact with each other. The marginality in which he had lived allowed Madruzzo to look with lucidity at the pretensions that were on either side of the border. He could then offer "a point of reference for those who hoped for a Council where they could finally talk openly about the serious problems of the moment and let the positive method of reform triumph." ${ }^{26}$ Unfortunately, the reasons for diversity prevailed over the hopes for cohesion; the power of Charles $\mathrm{V}$ collapsed rapidly and the pluralism of confessions in the individual territorial states was accepted precisely to set aside any idea of founding a universal monarchy. The subsequent division and belonging to one of the religious groups that was then being formed was precisely

24. The theory of justification by faith alone, developed by Luther, states that faith is a gift of God's mercy, which places the justice of Christ through faith on Christians, otherwise impossible to deserve. Actions are possible only if there is faith, which in any case is sufficient for justification. The Council of Trento will reaffirm the importance of faith for justification, but it reiterates that salvation is a condition that is achieved gradually, not an event achieved once and for all, at the beginning of the Christian experience, by the believer. Salvation is achieved by personal merit, in the sense of a response to divine grace. On the theme see in particular V. Subilia, La Giustificazione per Fede (Brescia: Paideia, 1976); F. Ferrario and W. Jourdan, Per Grazia Soltanto. L'Annuncio della Giustificazione (Turin: Claudiana, 2005).

25. "Christopher Madruzzo, in the last years of his life, had often been heard to say that he was proud of two things "mainly in this world: one was to have served Charles V Emperor, the other to have loved and venerated the Cardinal of England", M. Bellabarba, "Il Principato Vescovile di Trento e i Madruzzo: 1'Impero, la Chiesa gli Stati Italiani e Tedeschi," in Dal Prà (Ed.) I Madruzzo e l'Europa 1539-1658. I Principi Vescovi di Trento tra Papato e Impero, 1993, 29. Some historians remember how much the bishop could be one of the "very authoritative exponents of the ecclesiastical hierarchy" who had become "unscrupulous propagandists" of doctrines that were manifestly unorthodox, reiterating that "some of the most prestigious exponents of the sacred college, often linked to the imperial party, did not cease to look at those doctrines with curiosity, interest and in some cases personal involvement". See M. Firpo, Riforma Protestante ed Eresie nell'Italia del Cinquecento (Rome-Bari: Laterza, 2004), 129-130; Firpo, Dal Sacco di Roma all'Inquisizione. Studi su Juan de Valdés e la Riforma Italiana (Turin: Edizioni dell'Orso, 1998), 64-104.

26. Prosperi, L'Eresia del Libro Grande. Storia di Giorgio Siculo e della Sua Seta, 2000, 90. 
what was fundamental for future relations between state units in the late $16^{\text {th }}$ century.

\section{Castel Velturno, a Border Utopia}

The construction works on behalf of Madruzzo of Castel Velturno - a summer residence of the prince-bishop near Bressanone in South Tyrol - has been attested since 1577 under the direction of architect Matthias Parlati. ${ }^{27}$ The studies have retraced the construction history of the residence starting from an analysis of the Libro dei conti. It provides precise information about the artists who worked on the site, as well as on the works carried out and their completion reported in 1589 , the year in which the castle can be said to be finished in all its parts. Castel Velturno consists of two floors in addition to the ground floor, used mainly as a warehouse. The decorative cycles of the rooms on the first floor can be traced back to Michele and Orazio da Brescia, while those on the second floor are named Pietro Bagnatore. The arrangement of the five rooms that make up the various floors follows the Oltradige scheme, with rooms symmetrically arranged on the sides of a central hall. What we intend to focus on in this essay is the choice of the iconographic programme of the pictorial decorations in the rooms of the castle, which forms a precise itinerary for the visitor to follow, divided into real cycles. In the eyes of Madruzzo, in Castel Velturno, what historically had not been possible to reach can happen. The residence is a real border space, a space that proposes a way of pacification. In this regard, the client's choice is to gather a large part of the iconographic programme from prints by Flemish artists of the time that represent the perfect union between Europe and Rome, as they were formed in the capital and then spread the Renaissance culture in the most remote areas of the Empire and acted as a glue between the centre and the border of Christianity ${ }^{28}$ (Figures 34).

27. On Castel Velturno, its composition and decorative cycles: N. Rasmo, "Le Pitture del Castello di Velturno," Alto Adige (1942): 82-100; L. Andergassen, Castel Velturno: La Residenza Estiva dei Principi Vescovi (Bolzano: Schnell Steiner Editore, 2010); S. Theil, Castel Velturno (Bolzano: Athesia Editore, 1984); K. Wolfsgruber, Castel Velturno: Costruzione e Decorazione (Bolzano: Soprintendenza Provinciale ai Beni Culturali, 1995); C. Limentani Virdis, "La Decorazione di Castel Velturno: Theatrum Totius Sapientiae," in L. Dal Prà (ed.) I Madruzzo e l'Europa 1539-1658. I Principi Vescovi di Trento tra Papato e Impero. Milan: Charta Editore, 1993, 268-277; S. Spada, "I Dipinti di Pietro Maria Bagnatore nel Castello di Velturno," in L. Dal Prà (ed.) I Madruzzo e l'Europa 1539-1658. I Principi Vescovi di Trento tra Papato e Impero. Milan: Charta Editore, 1993, 256-267.

28. See Limentani Virdis, "La Decorazione di Castel Velturno: Theatrum Totius Sapientiae," 1993, 269-270. 


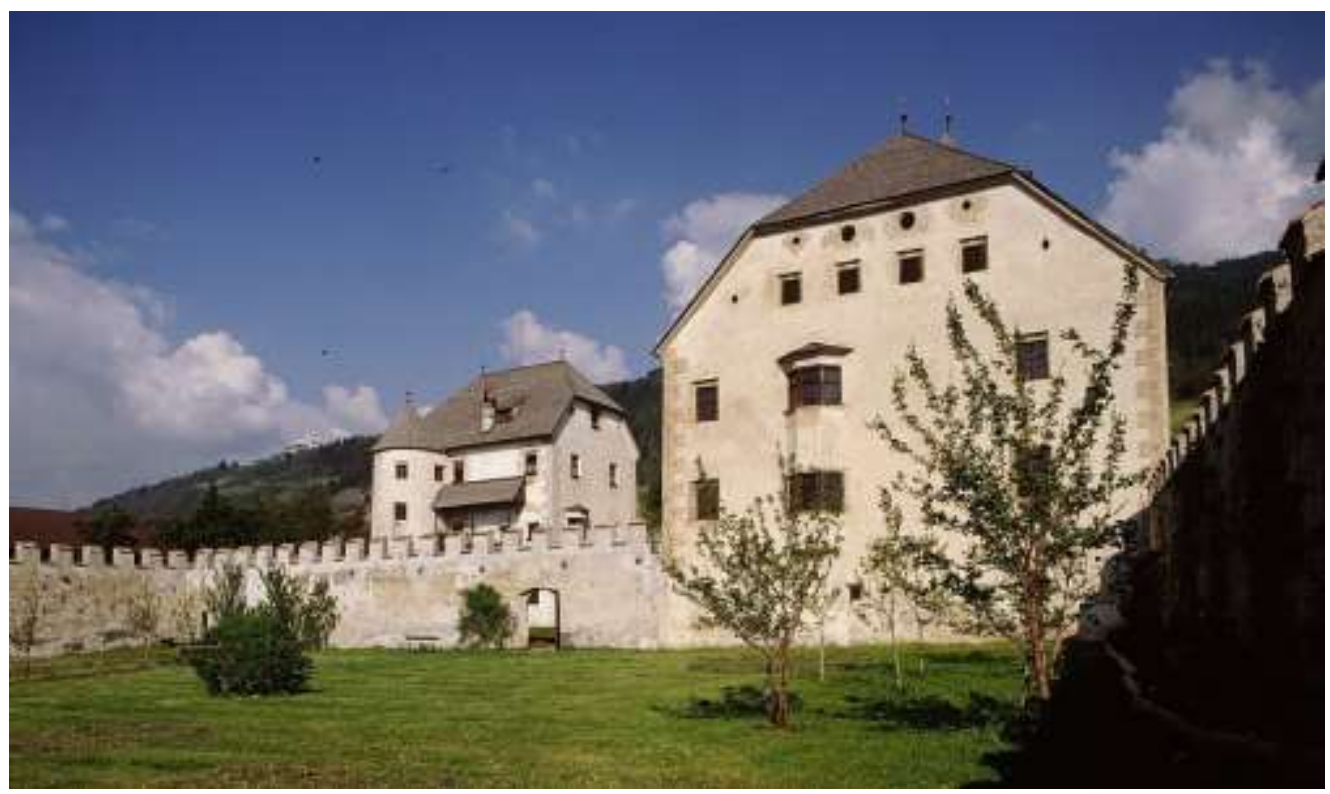

Figure 3. External View of Castel Velturno

Source: Autonomous Province of Bolzano - Cultural Heritage Office.

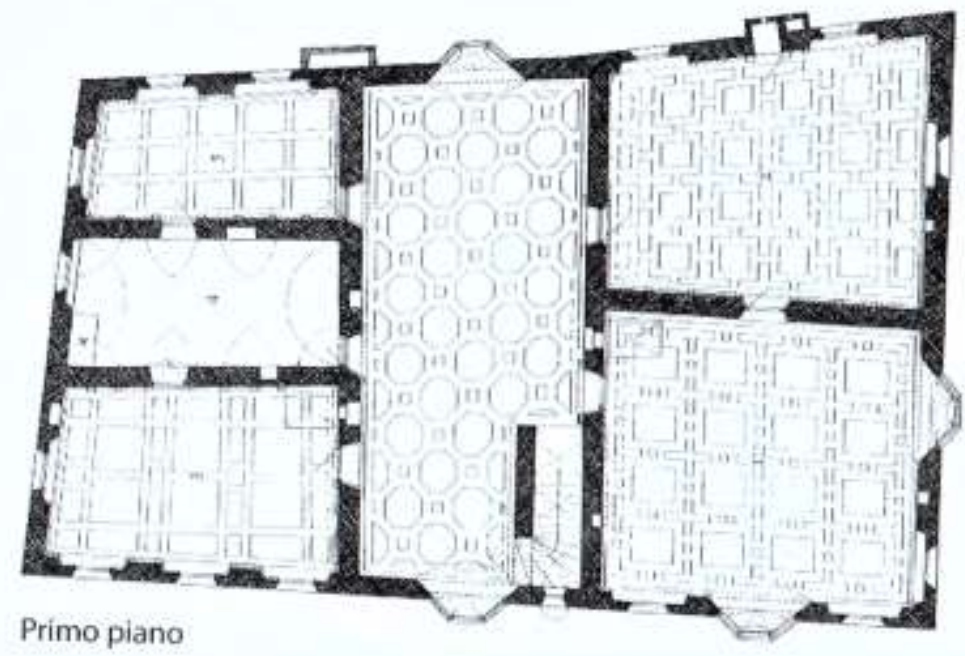

Figure 4. Blueprint of Castel Velturno (First Floor)

Source: Autonomous Province of Bolzano - Cultural Heritage Office.

\section{The "Fides" and the Dogmas of the Council of Trento}

The whole castle proposes, in the wall paintings, the continuous alternation between confessional subjects and profane allegories. The visitor is faced with allegories of the Sciences and Virtues in the first room. The second room contains remains of very faded decorations; the third room houses four panels with classical divinities: Jupiter, Juno, Mercury, Ceres and Proserpine, all accompanied by their attributes. In front of these, there are some panels among which the image of Fides 
stands out with torch and cross as opposed to Idolatry. The fourth room contains the representations of the Seven Sacraments, placed in front of the four episodes of the Parable of the Good Samaritan. In the final room, the pagan episodes return with paintings related to the Triumphs of Petrarch, the Four Seasons and episodes from the Stories of Aeneas. On the second floor, in the first room, in an almost mirror-like manner to that on the first floor, there are twelve panels on the Virtues that overcome the Vices, among which the painting representing the Christian Religion that conquers Idolatry is particularly noteworthy (Figure 5).

The second room includes a chapel, from where the visitor enters the third room, where the allegories of the four parts of the World and the five senses are represented. From the pagan repertoire, we pass again to scenes of a religious nature in the fourth room, all dedicated to a rich cycle with scenes from the Childhood of Jesus.

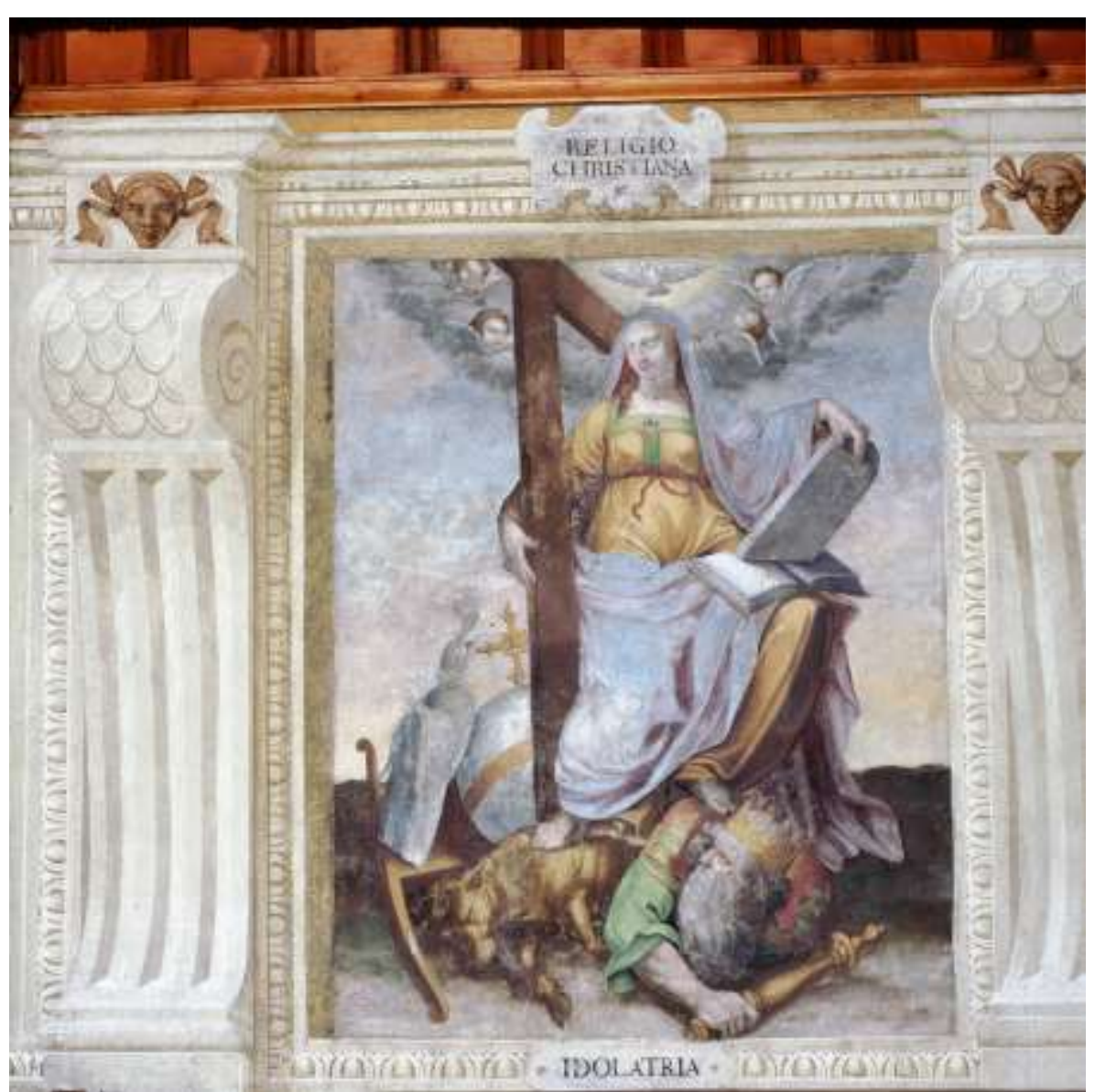

Figure 5. Pietro Bagnatore, Christian Religion wins over Idolatry, Detail of the Cycle of Virtues and Vices, Second Floor, 1584

Source: Autonomous Province of Bolzano - Cultural Heritage Office.

The atypical ascensional route proposed to the visitor, oscillating between the sacred and the profane, culminates in the fifth room, the so-called "Prince's room". This is the most important because it was used by the prince-bishop as a place of representation and a place for public audiences. 
The panels that decorate the room represent the Wonders of the ancient world, also taken from the famous series by Marteen van Heemskerck in 1570. To this some monuments are added that are not included in the traditional list, but are of great importance for the interpretation of the entire pictorial cycle: the Colosseum, an obelisk, the Trajan's Column, the Pyramid Cestia, the Temple of Jerusalem, the Tower of Babel, the allegory of Architecture with team and compass and finally the Saint Peter's Basilica (Figures 6-7).

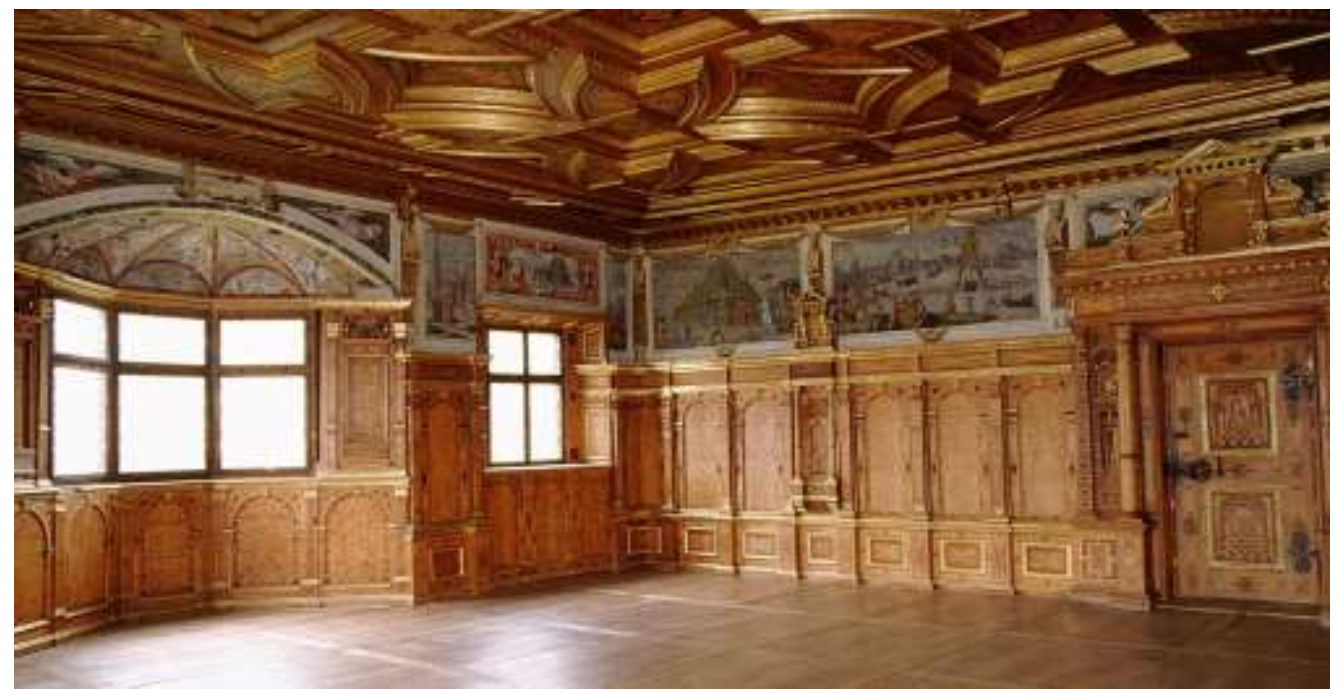

Figure 6. Corner view of the Prince's Room with Paintings of the Wonders of the Ancient World

Source: Autonomous Province of Bolzano - Cultural Heritage Office.

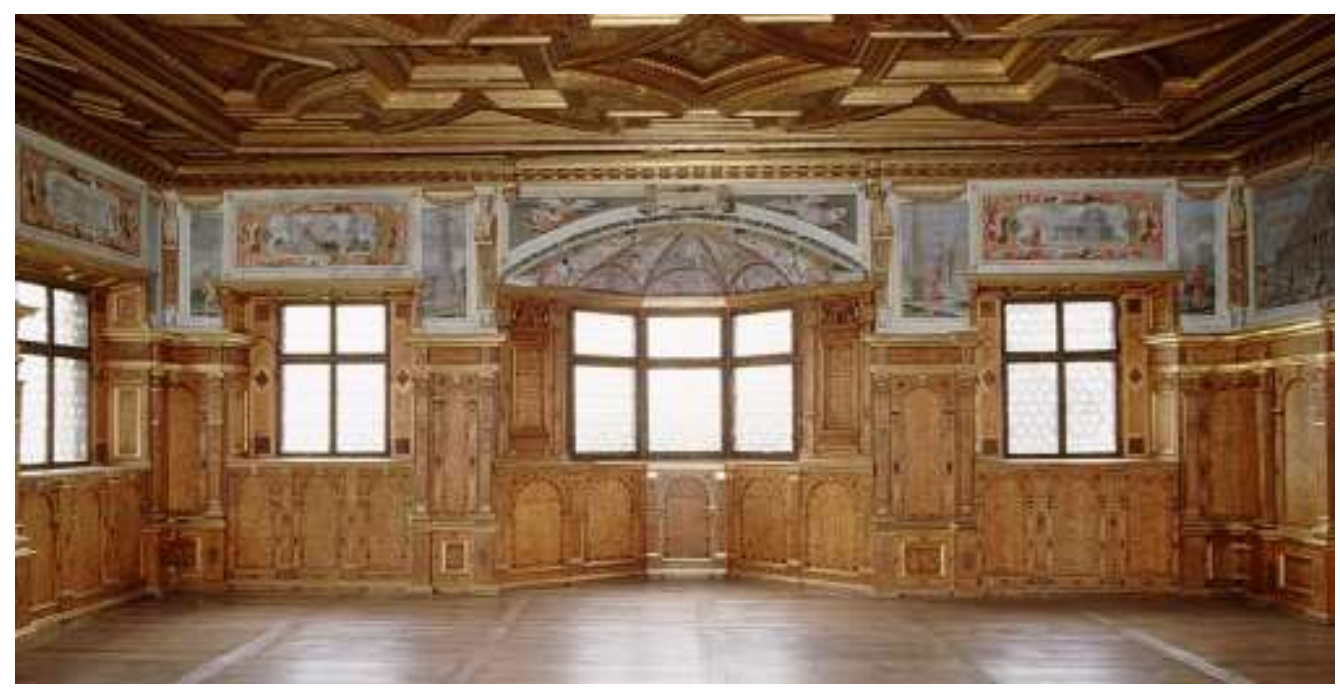

Figure 7. Detail of the Prince's Room with Panels of the Tower of Babel and St. Peter's Basilica

Source: Autonomous Province of Bolzano - Cultural Heritage Office.

The entire iconographic programme, according to Limentani Virdis, must be read in virtue of the contrast between Idolatry and Faith that would justify the presence of painted scenes such as the one in the north-west room on the first 
floor, where the winning Fides appears before the representatives of paganism. ${ }^{29}$ This character of "contraposition" can also be seen on other occasions, such as in the room dedicated to Virtues and Vices, where everything is a function of the Good-Evil contrast: the allegory of Power is opposed to Tyranny, Wisdom to Ignorance, Justice to Violence and so on. The scholar concludes by emphatically naming the iconographic programme of Castel Velturno Theatrum totius Sapientiae, in which the subjects of the painted scenes respond to the client's need for an ordered and severe encyclopaedic knowledge. Rather than a contraposition, it is possible to identify a co-presence of pagan and Christian in the whole iconographic programme studied and wanted by Madruzzo himself. This can only happen through a common thread that is given by the image of Fides. It is Fides that moves through the various rooms of the palace, bringing opposition on one side and co-presence on the other. The representation of the dogmas pronounced following the heated doctrinal discussions that took place in Trento is also evident. In particular, it is good to look at the cycle of the Seven Sacraments, one of the most important elements of Roman doctrine challenged by the Reformed. During the meetings of the second and third periods, the Council had set the number of sacraments at seven, putting an end to a confessional dispute of epochal importance. ${ }^{30}$ The depiction of the sacraments is almost literal in the room in the east wing on the first floor. See, for example, the sacrament of the Eucharist imparted here, just as contemplated by the Council of Trento, even outside the celebration of Mass $^{31}$ (Figure 8).

29. Limentani Virdis, "La Decorazione di Castel Velturno: Theatrum Totius Sapientiae," 1993, 272.

30. In several sessions, the general doctrine of the seven sacraments, considered to have been instituted by Jesus Christ and to be effective independently of their execution (former works), was reaffirmed. While the Council failed in its task of recomposing the Protestant schism and restoring the unity of the Church, it certainly provided an organic and comprehensive doctrine on the sacraments, which had been so much challenged by Luther. The sessions reserved for discussion of the sacraments were as follows: VII (1547), XIII (1551), XIV (1551), XXI (1562), XXIV (1563).

31. In fact, a priest is represented before an altar, who gives communion to three kneeling believers. It is stated in the acts of the Council: "Furthermore, the Holy Council declares that with very pious and religious thought it was introduced in the Church of God to celebrate this very noble and venerable sacrament every year with singular veneration and solemnity and with a particular festivity, and to carry it with reverence and honour through the streets and public places, in processions". Concilio di Trento, Decreto sull'Eucarestia, Sessione XIII, Capitolo V, Del Culto e della Venerazione Dovuti a Questo Santissimo Sacramento (11 Ottobre 1551), 221. 


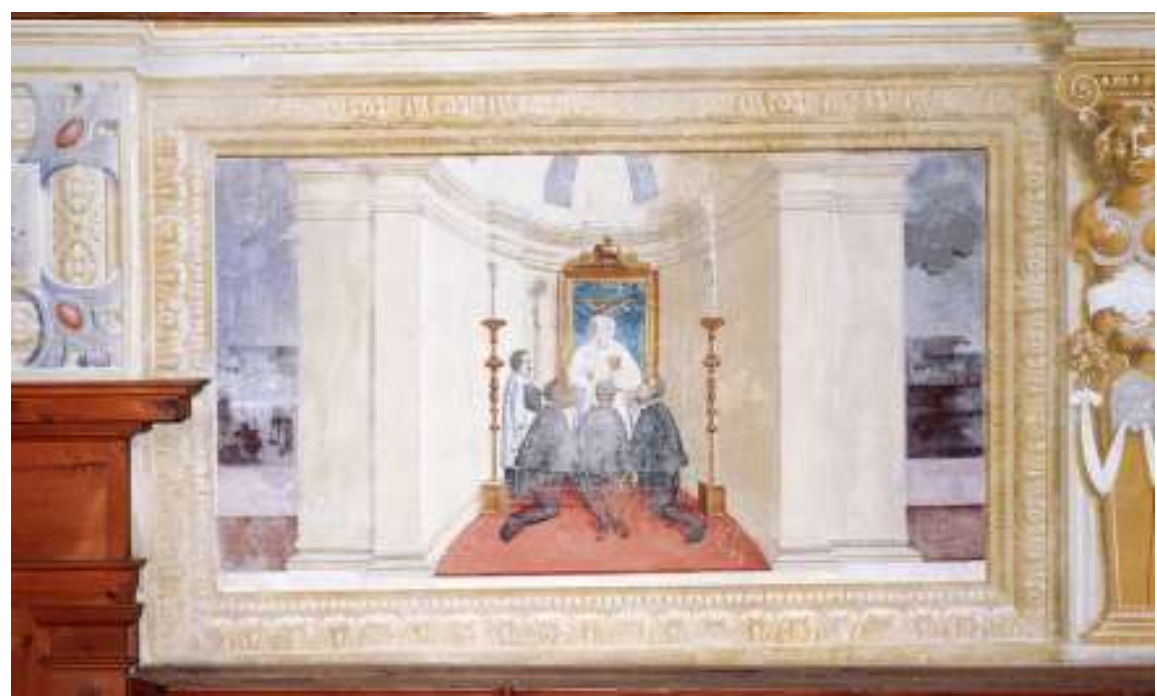

Figure 8. Orazio e Michele da Brescia, The sacrament of the Eucharist, Detail of the Cycle on the Sacraments, 1582-1583

Source: Autonomous Province of Bolzano - Cultural Heritage Office.

Finally, it is very interesting to examine the iconographic choice made for the decoration of the "prince's room", with the cycle dedicated to the pagan theme of the Wonders of the World. The seven Wonders of the classical canon are flanked by the eighth Wonder par excellence: the Colosseum, celebrated by van Heemskerck himself in his series of Octo mundi miracula. But what is most surprising is the fact that this panorama of famous monuments of Antiquity widens to include other archetypes present in the caput mundi city, such as the Trajan's Column and the Obelisks (Figures 9-10).

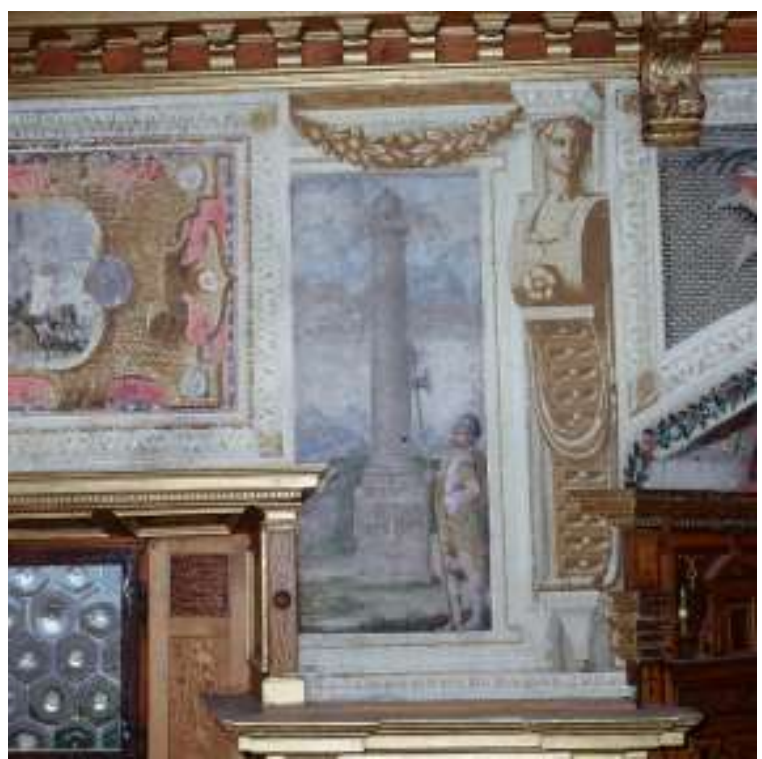

Figure 9. Pietro Bagnatore, Trajan's Column, Detail of the Wonders of the World Cycle, Prince's Room, Second Floor, 1584

Source: Autonomous Province of Bolzano - Cultural Heritage Office. 


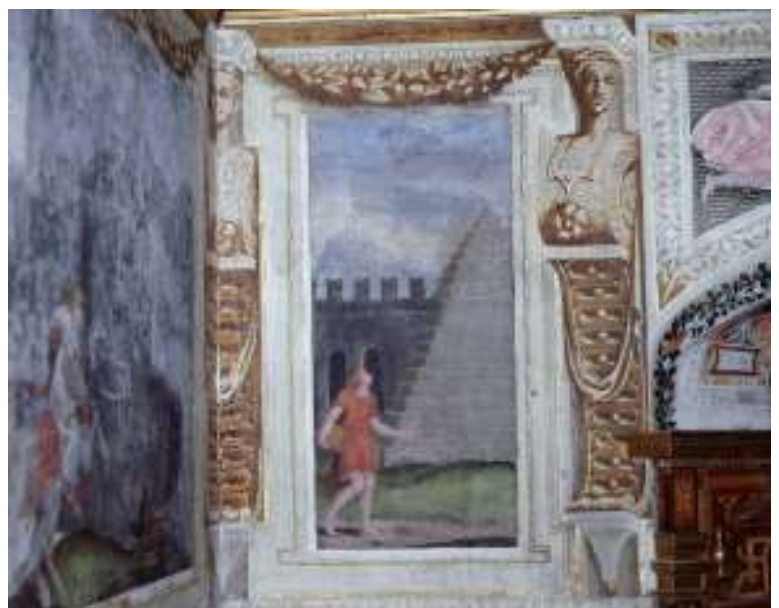

Figure 10. Pietro Bagnatore, Piramide Cestia, Detail of the Wonders of the World Cycle, Prince's Room, Second Floor, 1584

Source: Autonomous Province of Bolzano - Cultural Heritage Office.

Anticipating by about a century apart, the Kircherian juxtaposition between sacred and profane within the theme of the Mirabilia, this room becomes a real panorama of Wonders that sweeps towards the remotest Antiquity of the Christian world welcoming the ancient Biblical Wonders such as the Tower of Babel and the Temple of Jerusalem. For his personal room, Cristoforo Madruzzo still plays on the theme of the coexistence of two themes dear to him: Christian Fides and the choice of a pro-Imperial policy. The theme of Wonders appears as an important political support. These architectural works are the perfect expression of the "Ars regia", of that art born from the will of important political figures who see the works themselves as a manifestation of their power. It is not only the seven classical Mirabilia to be placed side by side in the painted scenes by the clients but the same figurative treatment is also reserved to the Christian Wonders. Next to the Tower of Babel is the Babylonian King Nebuchadnezzar while Solomon is at the side of the Temple of Jerusalem (Figures 11-13).

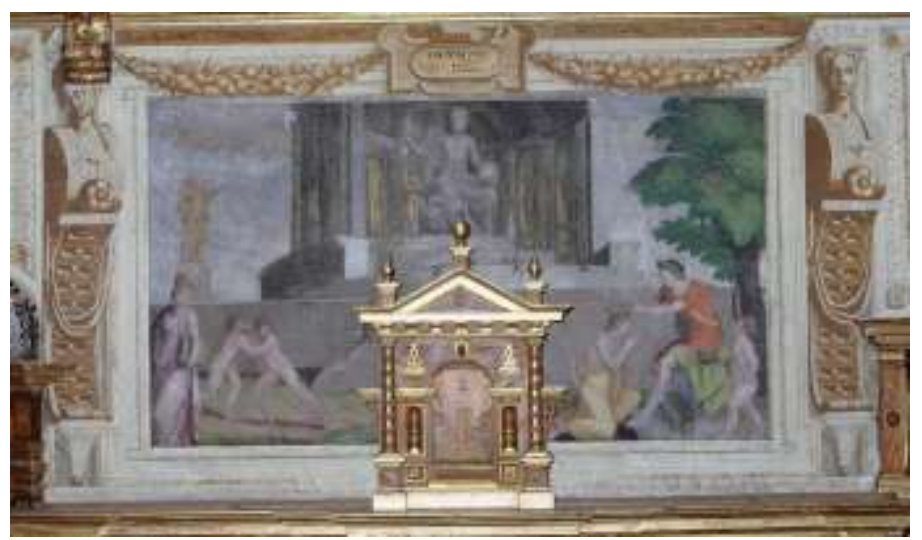

Figure 11. Pietro Bagnatore, The Statue of Zeus in Olimpia, Detail of the Wonders of the World Cycle, Prince's Room, Second Floor, 1584

Source: Autonomous Province of Bolzano - Cultural Heritage Office. 


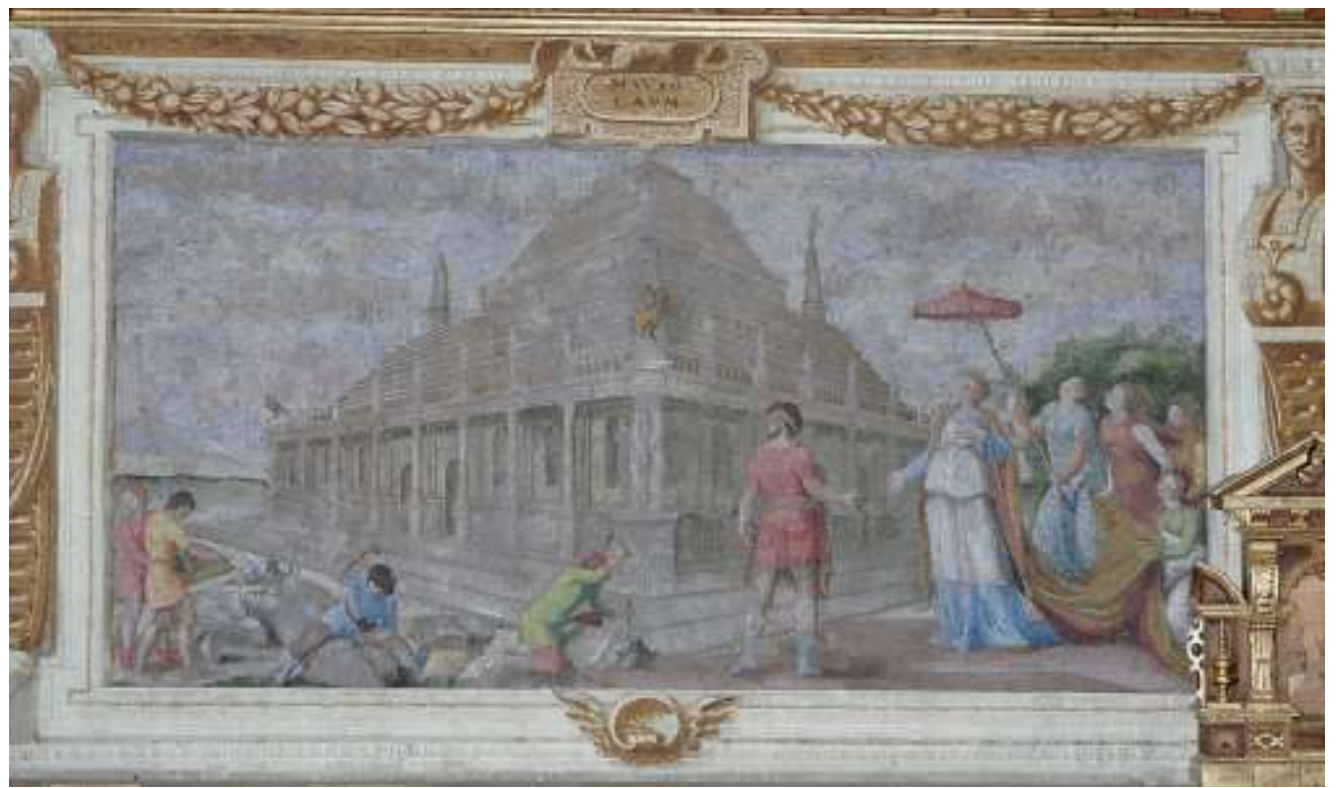

Figure 12. Pietro Bagnatore, The Mausoleum of Alicarnassus, Detail of the Wonders of the World Cycle, Prince's Room, Second Floor, 1584 Source: Autonomous Province of Bolzano - Cultural Heritage Office.

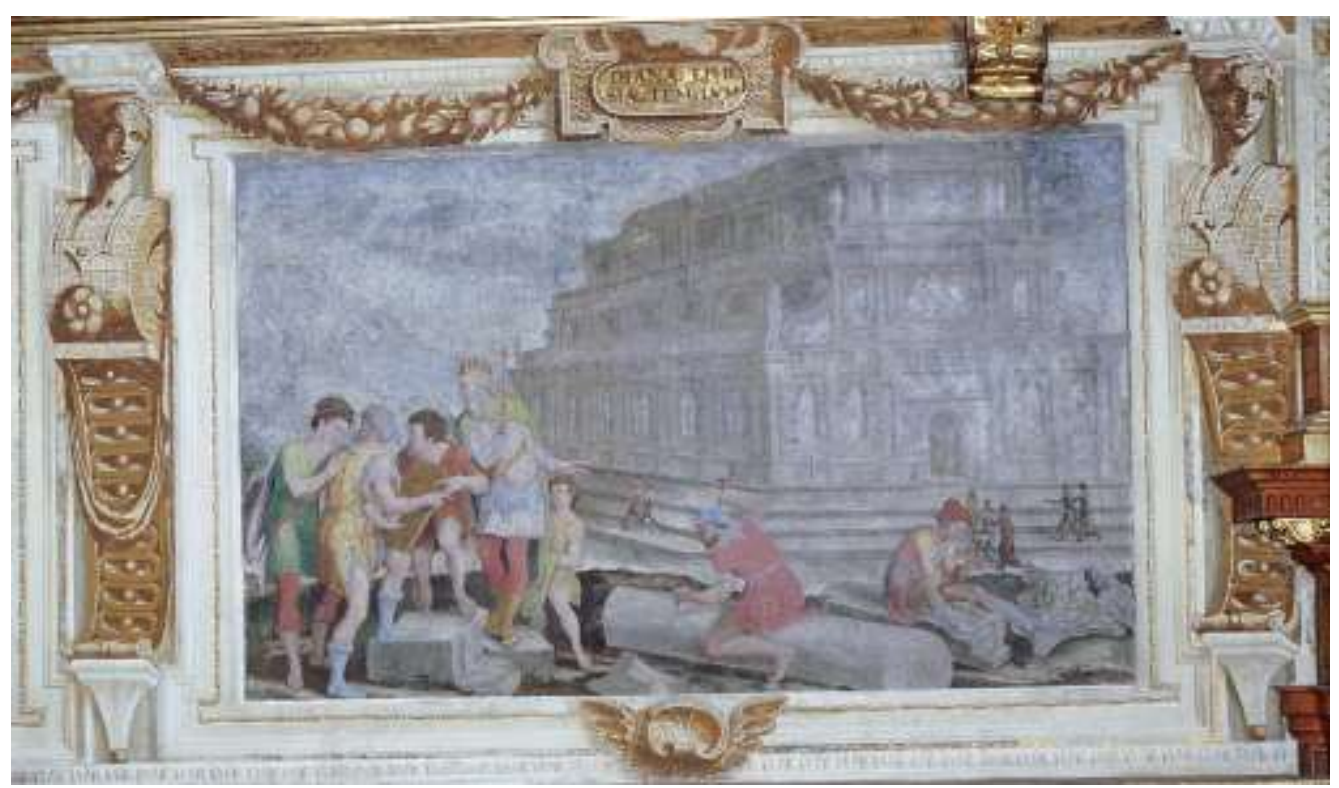

Figure 13. Pietro Bagnatore, The Temple of Artemis at Ephesus, Detail of the Wonders of the World Cycle, Prince's Room, Second Floor, 1584

Source: Autonomous Province of Bolzano - Cultural Heritage Office.

If the presence of negative archetypes of the Christian world (such as the Tower of Babel) recalls the weakness of those ancient Wonders built "without faith", in the "prince's room", it is also possible to look to the future, to the construction of that new Wonder. This on the one hand is the universal home of Christian Fides and on the other is the place where the greatest names of the artistic genius of the time alternate to the new St. Peter's Basilica. In a few words, 
the multiplicity of artistic inspiration blends into a single large casket in honour of Fides. It is not difficult to note how Madruzzo, in his decision to emphasise the decorative cycles of his castle with the recurring image of Fides, wishes to underline how convinced he is, supporting Lutheran beliefs that only Fides is the founding element of Religion capable of combining more distant positions and cultures. Faith must not be an element of rupture (as happened in the Council concerning the theories on justification). On the contrary, faith must be that binder which the Madruzzo family blindly believed. It was to be the mission of their bishop's policy when starting from the sixties of the $16^{\text {th }}$ century, they went to the court of Emperor Ferdinand more and more often to convince him to publish the Tridentine norms. There could not have been a better choice to represent Christopher's thought. In addition to being a tribute to van Heemskerck's famous drawing, St. Peter's Basilica is deliberately still under construction. This is not only because at the time of the execution of the mural paintings, it was not yet finished, but because the ideal that this work embodies, the universality of doctrine, has not yet been completely fulfilled. It is a battle to be won with the courage of those who challenge themselves for it. This is why the image of the building site is flanked by the two figures that, more than others, had been the driving force behind the architectural enterprise: Julius II and Michelangelo, represented here as a sculptor. As Zanini writes, "the boundary exists only in function of a centre." 32 Therefore, Castel Velturno exists only in function of its centre, Rome, the seat of Christian doctrine. History has also testified that the dream of Christopher and his family will never come true and that the peace of Westphalia reached in 1648 will represent the "end of the Madruzzian century." 33 With the fall of religious differences, confessional schemes and the need for mediation between the Germanic and Italian parts, the role of Madruzzo also lost its usefulness. However, Castel Velturno remained a significant utopia on the border between apparently opposing worlds.

\section{The Bi-National Community Skyscraper by C. Tzu Wei Chiang and A.M. Guerrero}

The border is very often understood as a fence, an element of definition of a closed and protected space that with its construction regulates the way the space is crossed. The fence builds a frontier, a complex dialogue between inside and outside, when it defines rules between being inside and moving outwards: "The fence circumscribes and regulates through the doors an open space that is considered in some way privileged and different from its antithesis: the outside."’34 Faced with the danger of disorder, the clearest spatial response is found in the request made by many, both in the United States and in Europe, for a sort of right

32. Zanini, Significati del Confine. I Limiti Naturali, Storici, Mentali, 1997, 43.

33. Bellabarba, "Il Principato Vescovile di Trento e i Madruzzo: 1'Impero, la Chiesa gli Stati Italiani e Tedeschi," 1993, 42.

34. M. Scolari, "Principi Compositivi,” Recinti, Rassegna, no.1 (1979), 41. 
of enclosure. ${ }^{35}$ This right would like to see legislatively recognized the possibility for anyone to get out of a territory, to isolate themselves from a whole, segregating themselves in their own idealized space: "For those who belong to this exceptional space, everyday reality becomes the reality inside the camp, behind its border. Everything else, what remains outside, beyond the fence, the reality of others, is transformed into something increasingly distant and indifferent." 36

\section{The "Walls of Shame"}

Today in the world there are many walls built to prevent and hinder the passage of civilians between different territories. "Wall of shame" is a phrase used to define these structures with a critical meaning. Shame refers, depending on the case, to those who took care of their construction, the people who suffered the consequences or the circumstances that led to their construction. In 1961, W. Ulbricht gave the order to block the road that marked the border between the East and West sectors of Berlin. A few days later, the Berlin Wall was born. For 28 years, it was the symbol of the Cold War, which had politically divided the world into two hemispheres: eastern and western. It was above all a symbol of hostility, segregation and incommunicability. ${ }^{37}$ However, despite that the wall has fallen, others remain standing. Walls that break families and entire peoples, that shatter identities, that deny hope. It starts with the one more than a thousand kilometers long, known as the wall of Tijuana, a metal sheet that covers a third of the border between the USA and Mexico. It was erected against the citizens of Central and South America, who are trying to reach the U.S. through the Mexican border to escape from hunger and misery still widespread in the Mexican state. No less famous is the mighty wall, $4 \mathrm{~km}$ wide, erected by the South Koreans, which divides Korea in two. This wall was created in 1977 and extends for $240 \mathrm{~km}$, for the total width of the peninsula. Not to be forgotten is the $27 \mathrm{~km}$ long Malaysia/ Thailand wall, built by the Thais on the border with Malaysia, to counter the arrival of weapons intended for the Muslim and separatist guerrillas in the south of the territory. According to official sources, the Zimbabwe/Botswana wall, an electrified barrier is created, to prevent wild animals from passing from one country to another. But in reality, it was built to prevent refugees, escaping the ethnic massacres of Zimbabwe, from entering Botswana, a small nation with one of the highest incomes in Africa. And then, there were many small "Gaza Strips": villages of the African communities San and Herero cut in two or deprived of water access roads, where bloody guerrillas are constantly taking place. On the one hand, the villagers are trying to remove that intolerable barrier. On the other, the army of Botswana committed to enforce the demarcation of the border. In Central

35. S. Boeri, "Border Device(s): A Visual Essay," Borderlands: Identity, Culture and Belonging 120 (2005): 28-39.

36. Zanini, Significati del confine. I Limiti Naturali, Storici, Mentali, 1997, 130-131.

37. On the Berlin Wall and the studies after its fall see: P. Galante and J. Miller, The Berlin Wall (New York: Doubleday \& Co., 1965); R. Koolhaas, The Berlin Wall as Architecture ('Field Trip', SMLXL, 1995); P. Major, Behind the Berlin Wall: East Germany and the Frontiers of Power (Oxford: Oxford University Press, 2010); J. Ward, Post-Wall Berlin: Borders, Space And Identity (London: Palgrave Macmillan, 2011). 
Asia, on the other hand, there is a wall, equipped with sensors and video surveillance, erected by Uzbekistan to assert sovereignty over certain territories disputed with Kyrgyzstan. Between India and Pakistan, there is one of over three thousand kilometers that divides the two countries. Pakistan has built a 2,400 km barrier to control its border with Afghanistan while the Iranian government is completing the construction of a wall on the border with the Pakistani Republic. After six years of hard work, the wall dividing India and Bangladesh has also been inaugurated: an iron curtain 4,000 km long to curb immigrants, stop terrorists, drug traffickers and arms dealers. Morocco, too, is not free of walls. Around the Sahrawi region, a great bastion also known as the "safety belt" extends for almost $4,000 \mathrm{~km}$. Its function is to protect the country from the attempts of infiltration by the Polisario Front into the territories militarily occupied by Morocco. In the Middle East, Saudi Arabia has been no less: since 2003, it has been separated from Yemen by a belt made of reinforced concrete and equipped with electronic control apparatus, to block the illegal immigration of the Yemeni population. Another 900 km long ultra-modern barrier was created by Saudi Arabia in 2006 on the border with Iraq. And then there is the Kuwait/Iraq wall. Kuwait has reinforced the already existing $215 \mathrm{~km}$ long wall on the border with Iraq. And, again, the fence of the United Arab Emirates, built along the entire border, lines with the Sultanate of Oman. The "Walls of Shame" are also present in Europe; for example, the walls that divide Protestants and Catholics in Ireland (the so-called Peace Lines). When they were erected in the 1970s, they caused the deportation of entire families between the two areas. Between the Middle East and the West stands the electrified barrier that Spain has erected to block the passage of Moroccan or subSaharan immigrants. A double barrier stands from 4 to 6 meters high around the city of Ceuta and Melilla, where the pressure of millions of men on their way from sub-Saharan Africa is concentrated.

Thirty-one years after the fall of the Berlin Wall, Europe finds itself much more walled in than before. A thousand kilometers of weirs, fences, barbed wire and electrified nets have sprung up everywhere. The Balkans serve as a key part of the migration route from Turkey and Greece to Western and Northern Europe, and the UN's migration agency, IOM, estimates that nearly 22,000 asylum seekers and migrants are currently stranded in the region. Since the start of Europe's migrant crisis in 2015, at least 800 miles of fences have been erected by Austria, Bulgaria, Greece, Hungary, Macedonia, Slovenia and others - a rapid reaction in front of millions of people arriving in Europe from war zones from Afghanistan to Syria. These arrivals fed into a charged political environment over migration during the pandemic and led European countries to increase its military presence along borders to help fight illegal migration.

\section{The Project}

The walls, which over time have taken on the role of visible and invisible barriers can be rethought as a real threshold, a place destined to meet and open up to the differences in order to overcome the crisis caused by the closure of borders: "But can a new form of citizenship become the frontier that allows the cohabitation 
between different identities while safeguarding the confrontation with them?"38 Since the early 2000s, architects Ronald Rael and Virginia San Fratello have developed numerous proposals for interventions and alternatives to the United States-Mexico border wall (Figures 14-15).

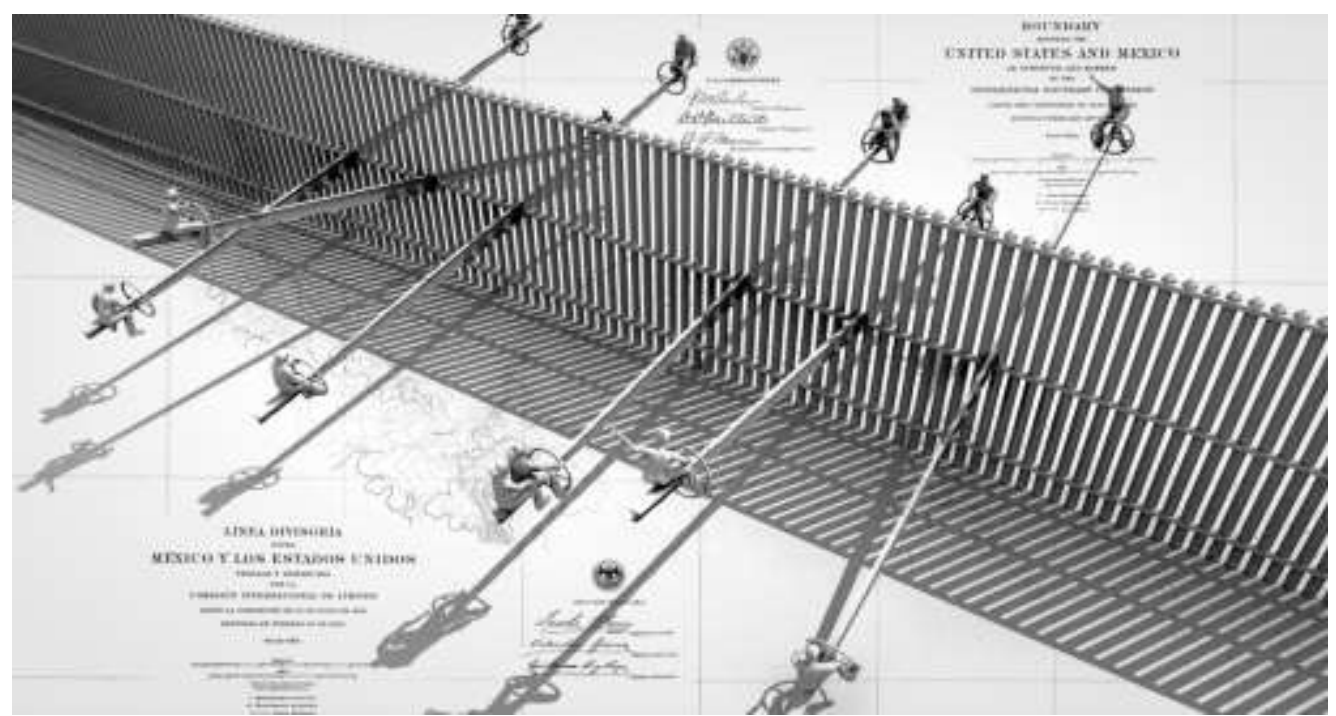

Figure 14. Ronald Rael and Virginia San Fratello, Transforming the Border Wall into a Teeter-Totter, USA-Mexico, 2019

Source: https://dezignark.com/.

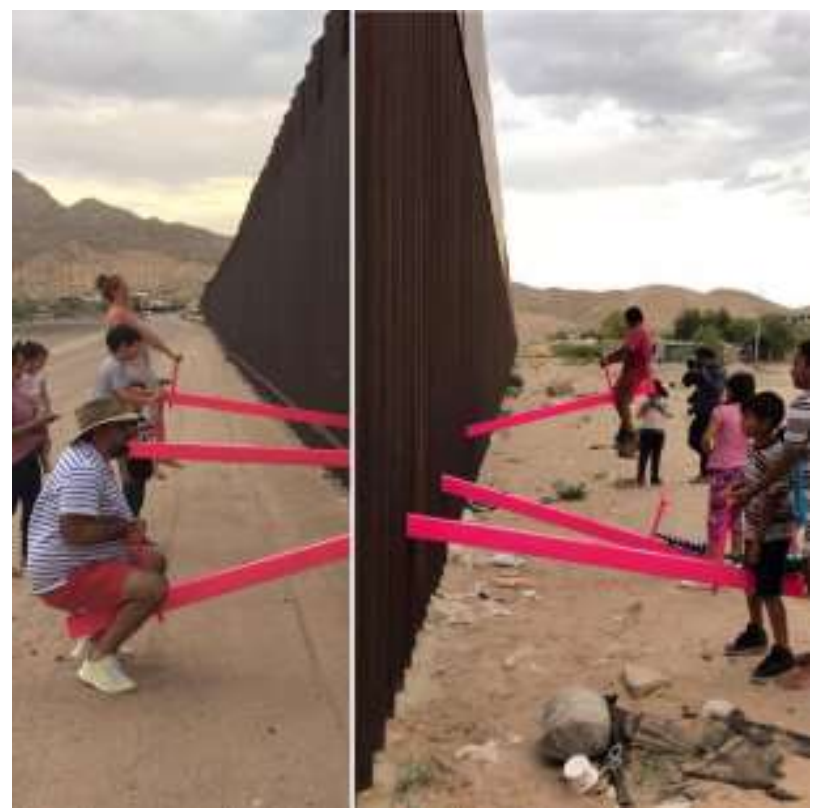

Figure 15. Ronald Rael and Virginia San Fratello, Transforming the Border Wall into a Teeter-Totter, USA-Mexico, 2019

Source: Wikimedia Commons.

38. Zanini, Significati del Confine. I Limiti Naturali, Storici, Mentali, 1997, 86. 
Many of their designs were inspired by stories of people who, on both sides of the border, transform the wall, challenging its existence in remarkably creative ways. Among the most famous ones, is the installation created using three pink swings in the boundary wall for families to play on. ${ }^{39}$ A similar and exemplary project in this sense is the Bi-National community skyscraper by architects, Charles Tzu Wei Chiang and Alejandro Moreno Guerrero of Taiwan, presented in 2019 at the "eVolo skyscraper competition". Established in 2006, the annual Skyscraper Competition is one of the world's most prestigious awards for highrise architecture. It recognises outstanding ideas that redefine skyscraper design through the implementation of novel technologies, materials, programs, aesthetics, and spatial organisations; along with studies on globalisation, flexibility, adaptability, and the digital revolution. It is a forum that examines the relationship between the skyscraper and the natural world, the community and the city. ${ }^{40}$ In 2019, one of the projects that received the honourable mention was the BiNational community skyscraper. The recent American government intends to enhance the construction of the border between Mexico and the U.S. to reinforce control. The barrier, which runs for miles along the border between Tijuana and San Diego (the size would be comparable only to the Great Wall of China) began to be built in 1990 cutting through deserts, mountains, rivers and cities. It is made of metal sheet, two to four meters high, and is equipped with very high-intensity lighting. A network of electronic sensors and night vision equipment is connected to radio to the US border police, who also use a permanent surveillance system with armed vehicles and helicopters. According to the data from Mexico's National Human Rights Commission, five thousand people have died in an attempt to cross the border in search of a more dignified existence. There are many stories regarding how such borders separate family members who hold different citizenship, or work and live on different sides of borders. This proposal aims to transform the perception of political borders from the boundary of separation to gathering for connection. Friendship Park is located next to the border between San Diego and Tijuana, as one of the locations where many separated families meet from both sides of the border. In the 1900s, there is no well-defined border but only patrols to control for access. Many travel back and forth to meet their family during weekends. Later, a metal fence was constructed to establish the border. In the 1990s, an additional metal mesh had been applied to prevent physical contact for illegal activities. Despite seeing each other through a metal mesh almost like seeing prisoners in jail, families are still willing to travel far to reunite on the border. This proposal suggests an "In-between zone" above the border fence, which is based on a temporary scaffolding structure and can be expended or reduced in size according to needs. With respect to legal regulation and the political situation, such a zone can be accessed with control of shafts of a staircase and allows families not only to meet up but hug and touch each other to share their moments together. As it serves as the platform for opportunities of interaction and communication, it enhances the interpersonal relationship and

39. See https://dezignark.com/blog/transforming-the-border-wall-into-a-teeter-totter-rael-sanfratello-artist-stories/. [Accessed 27 September 2020.]

40. See http://www.evolo.us/category/competition/. [Accessed 27 September 2020.] 
encourages a communal gathering space with a bi-national identity. As nationality or working and living status should not be the reason for the restriction of families to reunite, this project intends to help people who face the situation of separation of many families, as well as provide more humanised gathering space to meet on the border. Instead of constructing a structure of obstacle like a wall to reinforce control, the situation might be altered if a better architectural system can be provided and a better control method can be employed. A better outcome such as a bi-national community can be expected and encouraged to form (Figures 16-17).

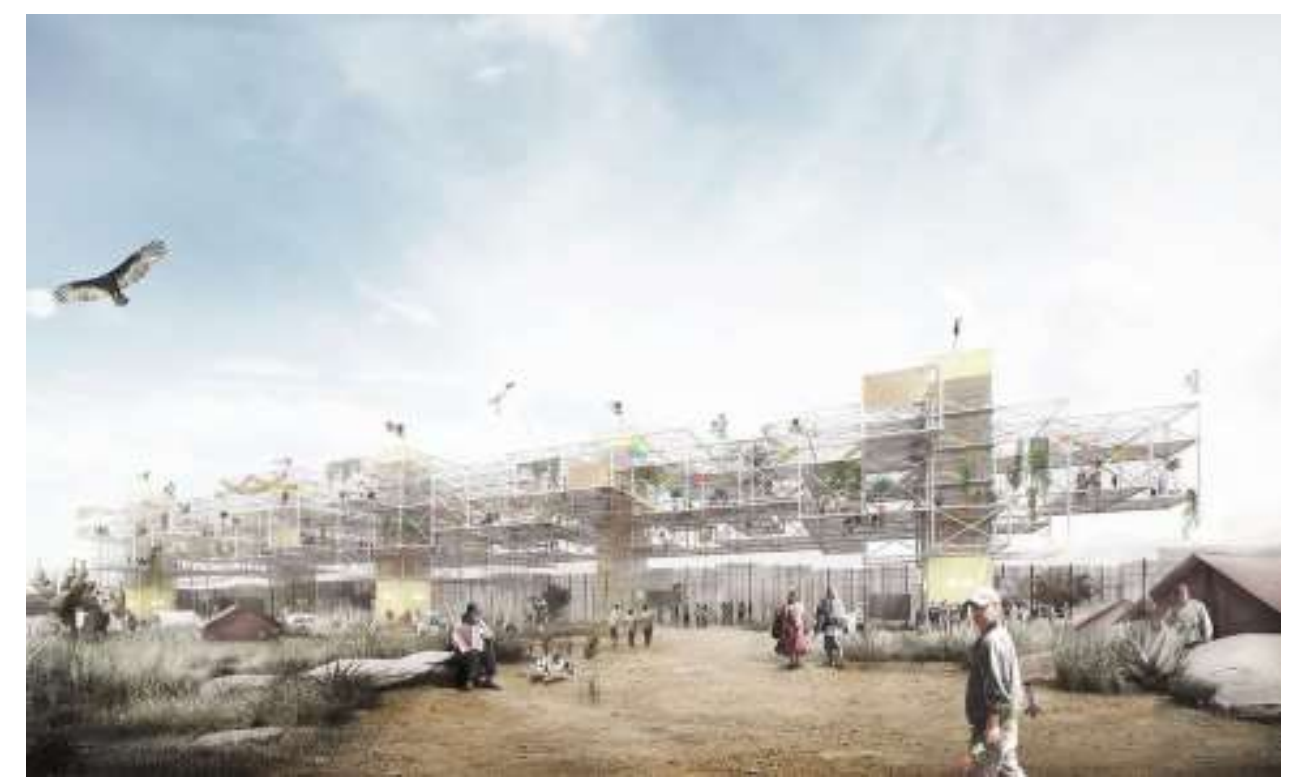

Figure 16. C. Tzu Wei Chiang, A. Moreno Guerrero, Bi-National Community Skyscraper, Project Hypothesis

Source: eVolo Competition 2019 (http://www.evolo.us/category/competition/).

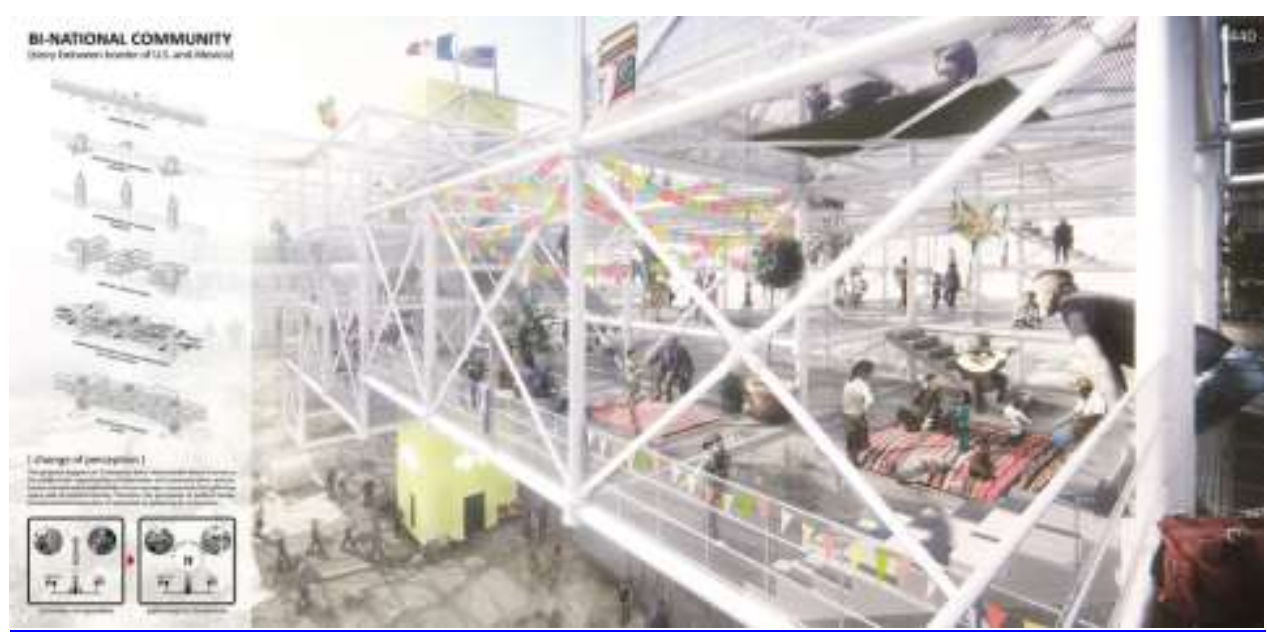

Figure 17. C. Tzu Wei Chiang, A. Moreno Guerrero, Bi-National Community Skyscraper, Project Hypothesis

Source: eVolo Competition 2019 (http://www.evolo.us/category/competition/). 


\section{Conclusions}

The three case-studies proposed, deliberately taken from very distant historical periods, help to understand that from an invisible place of separation to a space of misunderstanding, the border has also been understood in the past as the place of diversity, where different social groups and different ethnic groups meet and try to find a common modus vivendi, accepting each other. The frontier as a "space between two spaces" takes on positive and proactive characters and meanings, since it offers itself as a place of opportunities to undertake new experiences and new activities beyond the boundaries of tradition. Architecture, understood first of all as an instrument of measurement, is the ideal means to advance a semantic shift, proposing projects aimed at making the border a habitable place. Rethinking the border, nowadays, means making people understand that there is a mutual advantage in recognising the values of both sides. It would become not only a place but a real instrument to keep the dialogue open, beyond the respective ideological, religious or cultural schemes.

"This is where the modern world is born, and since everyday life requires a reasoned range of boundaries within which individual, family, community, city, regional, national and world life can take place, it is necessary that these boundaries are once again thought out and realised, and that they work both ways: open in certain circumstances, closed in certain others, like the simplest and oldest border, the door between two neighbouring rooms."

\section{Acknowledgments}

I would like to remember that this essay is the result of research funded by the European Union, European Regional Development Fund, PON Aim, Research and Innovation, International and Attraction mobility (2014-2020).

\section{Bibliography}

Albrecht, B. and L. Benevolo. I Confini del Paesaggio Umano. [The Boundaries of the Human Landscape.] Rome-Bari: Laterza, 1994.

Andergassen, L. Castel Velturno: La Residenza Estiva dei Principi Vescovi. [Castel Velturno: The Summer Residence of the Bishop Princes.] Bolzano: Schnell Steiner Editore, 2010

Angelillo, A. and C. Menato. Città di Confine. Conversazioni sul futuro di Gorizia e Nova Gorica. [Border towns. Conversations about the future of Gorizia and Nova Gorica.] Portogruaro: Ediciclo, 1994.

Augè, M. Tra i Confini. Città, Luoghi, Integrazioni. [Between the Borders. Cities, Places, Integrations.] Milan: Mondadori, 2007.

Bammer A. "A Peripteros of the Geometric Period in the Artemision of Ephesus." Anatolian Studies 40 (1990): 137-160.

Barbanera, M. "Favole Antiche e Mitologie Moderne. Le Competizioni Artistiche nella Storia dell'arte Greca." [Ancient Fables and Modern Mythologies. Artistic

41. Albrecht and Benevolo, I Confini del Paesaggio Umano, 1994, 115. 
Competitions in Greek Art History.] Atene e Roma. Rassegna dell'Associazione Italiana di Cultura Classica VIII, no. 1-2 (2014): 7-31.

Boeri S. "Border Device(s): A Visual Essay." Borderlands: Identity, Culture and Belonging 120 (2005): 28-39.

Bozzoni, C., Pardo, V. F., Ortolani, G. and A. Viscogliosi. L'Architettura del Mondo Antico. [Architecture of Ancient World.] Bari: Laterza, 2006.

Canizaro, V. B. Architectural Regionalism: Collected Writings on Place, Identity, Modernity and Tradition. New York: Princeton Architectural Press, 2012.

Cavallotto S. "Luterani e Cattolici, Storia di un Dialogo Mancato e Ritrovato." [Lutherans and Catholics, the Story of a Dialogue that has been Lost and Rediscovered.] Syzetesis V/2 (2018): 227-250.

Clayton, P. A. and M. J. Price. Seven Wonders of the World. Turin: Einaudi, 1989.

Concilio di Trento, Decreto sull'Eucarestia. [Decree on the Eucharist.] Sessione XIII, Capitolo V, Del Culto e della Venerazione Dovuti a Questo Santissimo Sacramento, 11 Ottobre 1551.

Dal Prà, L. (Eds.) I Madruzzo e l'Europa 1539-1658. I Principi Vescovi di Trento tra Papato e Impero. [Madruzzo and Europe 1539-1658. The bishop Princes of Trento between the Papacy and the Empire]. Milan: Charta Editore, 1993.

De Giuliani C. Cristoforo Madruzzo. Giovinezza e Studi, sua Elezione a Principe-Vescovo di Trento e Cardinale. [Cristoforo Madruzzo. Youth and Studies, his Election as Prince-Bishop of Trento and Cardinal.] Archivio Trentino 20 (1905): 52-88.

Del Sole, F. Viaggio nella Meraviglia: Descrivere, Immaginare, Ri-Costruire. [Travel in the Wonder: Describe, Imagine, Re-Build.] Galatina: Congedo, 2019.

Del Sole, F. "The Gift of the Spoken Word: The Word-Image Relationship in the Memory Process." In New Approaches in Contemporary Architecture and Urbanism. Edited by H. A. Nia. Cinius Yayınları: Alanya, 2020, 106-114.

Fabietti, U. "La Costruzione dei Confini in Antropologia. Pratiche e Rappresentazioni." [The Construction of Boundaries in Anthropology. Practices and Representations.] In Confini: Costruzioni, Attraversamenti, Rappresentazioni. Soveria Mannelli: Rubbettino, 2005.

Fagiolo, M. Le Meraviglie e il Meraviglioso. [Wonders and the Wonderful.] Psicon. Rivista Internazionale di Architettura 7, no. III (1976): 3-9.

Falkener, E. Ephesus, and the Temple of Diana. London: Polity Press, 1862.

Ferrario, F. and W. Jourdan. Per Grazia Soltanto. L'Annuncio della Giustificazione. [By Grace Alone. The Announcement of the Justification.] Turin: Claudiana, 2005.

Firpo, M. Dal Sacco di Roma all'Inquisizione. Studi su Juan de Valdés e la Riforma Italiana. [From the Sack of Rome to the Inquisition. Studies on Juan de Valdés and the Italian Reformation.] Turin: Edizioni dell'Orso, 1998.

Firpo, M. Riforma Protestante ed Eresie nell'Italia del Cinquecento. [Protestant Reformation and Heresies in $16^{\text {th }}$ Century Italy.] Rome-Bari: Laterza, 2004.

Galante, P. and J. Miller. The Berlin Wall. New York: Doubleday \& Co, 1965.

Gallino, L. Globalizzazione e Disuguaglianze. [Globalization and Inequality.] Bari: Laterza, 2001.

Giddens, A. Modernity and Self-Identity. London: Polity Press, 1991.

Herle, P. and E. Wegerhoff. Architecture and Identity. Berlin: Lit Verlag, 2009.

Koolhaas, R. The Berlin Wall as Architecture. 'Field Trip', SMLXL, 1995.

La Cecla, F. Mente Locale, per un'Antropologia dell'Abitare. [Local Mind, for an Anthropology of Living.] Milan: Eleuthera, 1993.

La Cecla, F. Il Malinteso: Antropologia dell'Incontro. [The Misunderstanding: Anthropology of the Encounter.] Rome-Bari: Laterza, 2003. 
LiDonnici, L. R. The Images of Artemis Ephesia and Greco-Roman Worship: A Reconsideration. Harvard Theological Review 85, no. 4 (1992): 389-415.

Limentani Virdis, C. "La Decorazione di Castel Velturno: Theatrum Totius Sapientiae." [The Decoration of Castel Velturno: Theatrum Totius Sapientiae.] In I Madruzzo e l'Europa 1539-1658. I principi Vescovi di Trento tra Papato e Impero, 268-277. 1993.

Madonna, M. L. Septem Mundi Miracula come Templi della Virtù. [Septem Mundi Miracula as Temples of Virtue.] Psicon. Rivista Internazionale di Architettura 7, no. III (1976): 25-31.

Magnaghi, A. Il Progetto Locale. Verso la Coscienza di Luogo. [The Local Project. Towards the Consciousness of Place.] Turin: Bollati Berlinghieri, 2010.

Magris, C. "Come i Pesci il Mare." [Like Fish, the Sea.] Frontiere - Nuovi Argomenti 38 (1991).

Major, P. Behind the Berlin Wall: East Germany and the Frontiers of Power. Oxford: Oxford University Press, 2010.

Paba, G. (Ed.) La Città e il Limite. I Confini della Città. [The City and the Limit. The Boundaries of the City]. Florence: La Casa Usher, 1990.

Pliny the Elder. Naturalis Historia. [Natural History.] Pisa: Giardini, 1985.

Prosperi, A. L'Eresia del Libro Grande. Storia di Giorgio Siculo e della sua Setta. [The Story of Giorgio Siculo and his Sect.] Milan: Feltrinelli, 2000.

Rasmo, N. Le Pitture del Castello di Velturno. [Castel Velturno's Paintings.] Alto Adige (1942): 82-100.

Rella, F. Metamorfosi: Immagini del Pensiero. [Metamorphosis: Thought's Images.] Milan: Feltrinelli, 1984.

Remotti, F. Contro l'Identità. [Against Identity.] Bari: Laterza, 1996.

Rocco, G. "Guida alla Lettura degli Ordini Architettonici Antichi. II. Lo Ionico.” [Guide to the Reading of Ancient Architectural Orders. II. The Ionic.] In Guide di Ricerca Storica e Restauro 4, 75-82. Naples: Liguori Editore, 2003.

Rykwert, J. and G. Scattone. L'idea di Città. Antropologia della Forma Urbana nel Mondo Antico. [The Idea of a City. Anthropology of the Urban Form in the Ancient World.] Turin: Einaudi, 1981.

Salvatici, S. (Eds.) Confini: Costruzioni, Attraversamenti, Rappresentazioni. [Boundaries: Constructions, Crossings, Representations.] Soveria Mannelli: Rubbettino, 2005.

Scolari, M. "Principi Compositivi." [Compositional Principles.] Recinti, Rassegna, no. 41 (1979).

Spada, S. I Dipinti di Pietro Maria Bagnatore nel Castello di Velturno. [The Paintings of Pietro Maria Bagnatore in the Castle of Velturno.] In I Madruzzo e l'Europa 1539. 1658. I Principi Vescovi di Trento tra Papato e Impero, 256-267. 1993.

Strabo. Geography. Milan: Rizzoli, 1993.

Subilia, V. La Giustificazione per Fede. [The Justification by Faith.] Brescia: Paideia, 1976.

Theil, S. Castel Velturno. Bolzano: Athesia Editore, 1984.

Varzi, A. C. "Teoria e Pratica dei Confini." [Boundary Theory and Practice.] Sistemi Intelligenti 17, no. 3 (2005): 399-418.

Ward, J. Post-Wall Berlin: Borders, Space and Identity. London: Palgrave Macmillan, 2011.

Wolfsgruber, K. Castel Velturno: Costruzione e Decorazione. [Castel Velturno: Construction and Decoration.] Bolzano: Soprintendenza Provinciale ai Beni Culturali, 1995.

Zanini, P. Significati del Confine. I Limiti Naturali, Storici, Mentali. [Meanings of the Border. Natural, Historical, Mental Limits.] Milano: Mondadori, 1997. 